Universal Decimal Classification (UDC) number 613.2/3

\title{
THE DEVELOPMENT OF A METHOD FOR CHLORAMPHENICOL DETERMINATION IN MEAT PRODUCTS
}

\author{
T.S. Ulanova ${ }^{1}$, T.D. Karnazhitskaya ${ }^{1}$, \\ Ye.O. Pshenichnikova ${ }^{1}$, E.A. Nakhieva ${ }^{1,2}$ \\ ${ }^{1}$ FBSI «Federal Scientific Center for Medical and Preventive Health Risk Management Technologies», \\ Russian Federation, Perm, 82 Monastyrskaya St., 614045, \\ ${ }^{2}$ Federal State Budget Educational Institution of Higher Professional Education «Perm State National \\ Research University», Russian Federation, Perm, 15 Bukireva St., 614990
}

\begin{abstract}
The results of the studies focused on the development of a technique for chloramphenicol detection in meat products using liquid chromatography-mass spectrometry (LC-MS) method are shown. During the studies, the optimum conditions were developed for chloramphenicol analysis using Agilent 1200 Series liquid chromatography system combined with mass-spectrometric detector with 6490 Triple Quadrupole LC/MS (Agilent Technologies). The conditions for efficient extraction of chloramphenicol from meat samples were studied. As an optimal variant, a method was selected using liquid extraction with ethyl acetate followed by purification of the extract with hexane. The recovery rate of the antibiotic from the matrix reaches $70-100 \%$, depending on chloramphenicol content in meat products. In the result of determination of metrological characteristics of the developed technique the following parameter values were obtained: accuracy - no more than $26 \%$, reproducibility - no more than $10 \%$, repeatability - no more than $5 \%$. Analysis of meat product samples carried out using the developed technique has demonstrated the presence of the antibiotic in $17.6 \%$ of samples.
\end{abstract}

Key words: chloramphenicol, veterinary drug, residues of veterinary drugs, meat products, liquid chromatography-mass spectrometry (LC-MS) method.

Chloramphenicol (levomycetin) is a broad-spectrum antibiotic. In veterinary medicine, chloramphenicol is used in livestock for treatment and prevention of infections caused by anaerobic bacteria or resistant to other antimicrobial agents. Chloramphenicol is well absorbed after oral and parenteral administration, slowly excreted from the animal body and the relatively long retains its activity in the stored products [13]. In the treatment of human, chloramphenicol is used with great caution. In the study of toxic effects of the drug, genotoxicity of chloramphenicol and its metabolites was demonstrated, as well as embryotoxicity, carcinogenic risk to humans and lack of "dose-response" correlation in cases of aplastic anaemia caused by chloramphenicol treatment $[8,10,11]$.

When consuming products of animal origin containing residues of veterinary drugs, the human body develops resistance to antibiotics, dysbacteriosis and allergic reactions may take

(C) Ulanova T.S., Karnazhitskaya T.D., Pshenichnikova Ye.O., Nakhieva E.A., 2013

Ulanova Tatiana Sergeyevna - Professor, DSc in Biology, Head of the Department of Analytical Chemistry Analysis (e-mail: ulanova@fcrisk.ru, tel.: 8 (342) 233-10-37).

Karnazhitskaya Tatiana Dmitrievna - PhD in Biology, Docent, Head of the Liquid Chromatography Laboratory (e-mail: tdkarn@fcrisk.ru, tel.: 8 (342) 233-10-37).

Pshenichnikova Yekaterina Olegovna - Chemist of the Liquid Chromatography Laboratory (e-mail: root@fcrisk.ru, tel.: 8 (342) 233-10-37).

Nakhieva Elza Askhatovna - Master's Degree Student (e-mail root@fcrisk.ru, tel.: 8 (342) 237-25-34). 
Experimental model and measurement studies

place, immunity is reduced. With constant consumption of food containing residues of veterinary drugs, the load on the organs and system responsible for the excretion of foreign compounds from the body (such as liver, kidneys) increases [2].

In the EU countries there is a prohibition operating against the content in foods of a number of veterinary drugs, including chloramphenicol. Thus, the regulations of the European Economic Community (EEC) No. 2377/90 from 1990 include substances which content in products is not allowed in raw and ready-to-use condition; these substances include chloramphenicol. The document of the Commission, Codex Alimentarius, approved in July 2012 at the 35th session of the Commission, lists the prohibited veterinary drugs, for which no permissible limit of residual content in the products can be established, as any amount of residues pose a risk to human health. This list includes chloramphenicol [7]. In the Russian legislation technical regulations of the Customs Union act, according to which the presence of chloramphenicol is not permitted in slaughterhouse material intended for use in meat products (note: $<0,0003 \mathrm{mg} / \mathrm{kg}$ ) [6].

The acting Methodological Guidelines MUK 4.1.1912-04 set the procedure for determination of chloramphenicol in foods of animal origin using two methods - liquid chromatography, which provides selectivity of determination, but has low sensitivity -0.01 $\mathrm{mg} / \mathrm{kg}$ (reference method), and enzyme immunoassay with high sensitivity of determination $(0.000012 \mathrm{mg} / \mathrm{kg})$, but insufficient specificity and reproducibility of the results [4]. In accordance with GOST R ISO 13493-2005 "Method for determination of chloramphenicol content using liquid chromatography", the minimum detectable concentration of chloramphenicol in meat is $0.0065 \mathrm{mg} / \mathrm{kg}$.

In order to provide the control of food product safety, it is important to improve the existing and to develop new, more sensitive and selective methods of analysis. Currently, the maximum sensitivity and the most accurate identification of complex organic compounds in food products and other biological samples is provided by modern instrumental methods, such as gas and liquid chromatography coupled to mass spectrometry (GC/MS and LC-MS) $[1,5,13]$.

The aim of the study was to develop a method for determination of chloramphenicol in meat products using liquid chromatography-mass spectrometry (LC-MS).

Materials and methods. The investigations were conducted in the Liquid Chromatography Laboratory of the Federal State-Funded Institution of Science "Federal Scientific Centre of medical preventive technologies of public health risk management" on Agilent 1200 Series liquid chromatograph with mass spectrometry detector with Agilent Technologies 6490 Triple Quadrupole LC/MS and electrostatic spraying ionization (ESI). As a 
Experimental model and measurement studies

standard sample, chloramphenicol with $\geq 98 \%$ purity was used (SIGMA-ALDRICH).

Development of methods for determination of chloramphenicol in food products included the following steps:

- Optimization of conditions for mass spectrometric analysis;

- Extraction of chloramphenicol from the sample and purification of the extracted sample;

- Quantification and qualitative confirmation of presence of chloramphenicol residues in the sample.

Optimization of mass spectrometric detector parameters for the qualitative determination of chloramphenicol was performed in automatic mode using "Optimizer" software. According to the literature, under conditions of electrostatic spraying ionization (ESI) negatively charged particles of chloramphenicol are registered, therefore, the investigation was carried out in the negative ionization mode.

In developing the optimal conditions for the chromatographic separation of a standard chloramphenicol sample with matrix components, first optimal wavelength of diode matrix detector was determined.

Analysis of separation of chloramphenicol with matrix components was carried using a column for reversed-phase chromatography: Poroshel 120 EC-C18, $50 \mathrm{~mm}$ long and an inner diameter of $3.0 \mathrm{~mm}$, particle size $2.7 \mu \mathrm{m}$; Eclipse XDB-C18, $150 \mathrm{~mm}$ long and an inner diameter of $21 \mathrm{~mm}$, particle size $5 \mu \mathrm{m}$; Bonus RP, $50 \mathrm{~mm}$ long and an inner diameter of 4.6 $\mathrm{mm}$, particle size $1.8 \mu \mathrm{m}$.

To identify the interfering effect of matrix components, samples of ground meat were analysed with and without addition of chloramphenicol in the optimal elution mode on the Bonus RP column.

The next stage of development of the technique for analysis of chloramphenicol in meat products included refinement of the method of sample preparation for analysis. Sample preparation affects all subsequent steps of analysis of the antibiotic, and is therefore crucial to the absolute identification, confirmation and quantitative analyte determination. Mass spectrometry allows the use of more simple universal purification methods. However, efficient purification of the matrix is a necessary measure, as the components present in the matrix can affect the performance of the mass spectrometer, in particular by reducing the detection signal [14].

To select an optimal method of meat product sample preparation for the analysis by liquid chromatography-mass spectrometry (LC-MS), experimental investigations were carried out aimed to determine the efficiency of chloramphenicol extraction from the matrix using the 
Experimental model and measurement studies

approaches recommended in scientific and methodological literature, which include liquid and solid phase extraction.

Investigations on determination of the recovery rate of chloramphenicol from meat samples were performed by analysis of spiked samples. A $10 \mathrm{~g}$ sample of ground meat was spiked with a known amount of chloramphenicol, setting a certain antibiotic concentration in the meat $(\mathrm{mg} / \mathrm{kg})$. The recovery rate was considered as a ratio of the amount recovered to the total (initial) amount of chloramphenicol in a sample according to the formula

$$
\mathrm{R}=\frac{A \cdot 100,}{N}
$$

where $R$ - the recovery rate of chloramphenicol, \%; $A$ - amount recovered, $\mu \mathrm{g} ; N$ - total (initial) amount of a substance, $\mu \mathrm{g}$.

Samples were assayed at optimal operating conditions of a chromatographic device and a mass spectrometer.

Technique of the procedure of the solvent extraction of an analyte from a biological matrix comprised sample homogenization, analyte extraction from the sample using suitable organic solvent, phase separation, and removal of proteins, lipids and other compounds from the extract. According to the literature, for solvent extraction of chloramphenicol from food products the following organic solvents were used: ethyl acetate, acetonitrile, ethyl acetate and acetonitrile, a mixture of chloroform and acetone, a mixture of acetonitrile and acetate buffer ( $\mathrm{pH}$ 5.0). Among these solvents ethyl acetate is most frequently used in chloramphenicol analysis.

Investigations on determination of the efficacy of chloramphenicol extraction from meat with ethyl acetate were carried out according to the following scheme: a $10 \mathrm{~g}$ sample of ground meat was spiked with $0.192 \mathrm{~g}$ chloramphenicol and extracted twice with $20 \mathrm{~cm}^{3}$ of ethyl acetate during $10 \mathrm{~min}$; the pooled extract was dried in air stream at $45{ }^{\circ} \mathrm{C}$ until oily residue was formed. The sample was purified from protein and fat adding methanol (for protein precipitation), sodium chloride salt and $20 \mathrm{~cm}^{3}$ of hexane (to remove fats) to the sample. After mixing and centrifugation, the hexane layer was discarded and re-purified. The remaining solution was extracted twice with ethyl acetate. The dried extract was re-dissolved in a methanol : water mixture and an aliquot was analysed on the device.

The sample preparation procedure provided ensures reliable and highly sensitive results of chloramphenicol analysis. Efficiency of extraction performed using this method was 70-99.9\%.

Under current Methodological Guidelines MUK 4.1.1912-04 chloramphenicol extraction is performed with ethyl acetate in the presence of buffer. Ethyl acetate extract was purified from impurities with petroleum ether and analysed by HPLC. 
Experimental model and measurement studies

The possibility of using QuEChERS method for sample preparation for chloramphenicol analysis was studied, which technically represents a dispersive solid phase extraction method and is successfully used in analytical chemistry for extraction of pesticides, antibiotics and other contaminants from food products of plant and animal origin. Sample preparation is based on the extraction of contaminants from a homogenized sample with acetonitrile in the presence of salts, mainly $\mathrm{MgSO}_{4}$ and $\mathrm{NaCl}$, under conditions of optimal $\mathrm{pH}$ of a medium set using buffer solutions and purification of the extract using bulk polymeric sorbents. Two variants of sample preparation according QuEChERS method were studied.

For quantitative determination of chloramphenicol, the external standard method was used - the relationship of the detector signal intensity from the analyte concentration in meat was determined and the calibration coefficient was calculated.

An important feature of the analysis of chemical compounds in biological substrates, which include food products, is the impact of a multicomponent matrix on the final result. To obtain reliable results of the analysis, an interfering effect of matrix components, the degree of analyte extraction, as well as inaccuracy of all stages of sample preparation for analysis must be taken into account $[1,3]$. In this regard, the construction of the calibration curve, samples containing a standard of chloramphenicol in the concentration range $0.00005-0.02 \mathrm{mg} / \mathrm{kg}$ were treated similarly to test samples - they were subject to extraction with ethyl acetate followed by purification with hexane. Prepared samples were analysed under optimal conditions by liquid chromatography-mass spectrometry (LC-MS) analysis.

Calibration factor was calculated according to the formula:

$$
K=\frac{\sum_{i=1}^{n} C_{i} S_{i}}{n},
$$

where $\mathrm{Ci}$ is a mass concentration of chloramphenicol in calibration solution, $\mathrm{mg} / \mathrm{kg}$; $\mathrm{Si}$ is an average of three measurements of chloramphenicol peak area of $\mathrm{i}$-th concentration, conventional units; $\mathrm{n}$ - number of calibration solutions.

For calculation of metrological indicators of the technique (precision, accuracy, repeatability, intermediate precision) methods of mathematical statistics were used.

Metrological indicators of the technique for determination of chloramphenicol in meat products were determined in accordance with the interstate standardization recommendations RMG 61-2010 "Indicators of accuracy, trueness and precision of quantitative chemical analysis techniques. Assessment methods" and GOST R ISO 5725-1 $\div 6-2002$ "Accuracy (trueness and precision) of the methods and results of measurements". To obtain experimental data, a series of 
standard samples of chloramphenicol in ground meat $(\mathrm{mg} / \mathrm{kg})$ was prepared with concentrations of chloramphenicol close to the lower, middle and upper values of the range of measured concentrations.

Results and discussion. When scanning daughter negatively charged ions in the coarse adjustment mode, a parent ion with mass to charge ratio $(\mathrm{m} / \mathrm{z})$ of 321 and 4 daughter ions with $\mathrm{m} / \mathrm{z}$ ratio of 152, 257, 151.2 and 121 were registered. Maximum detector response was obtained for daughter ions with $\mathrm{m} / \mathrm{z} 152$ and 257.

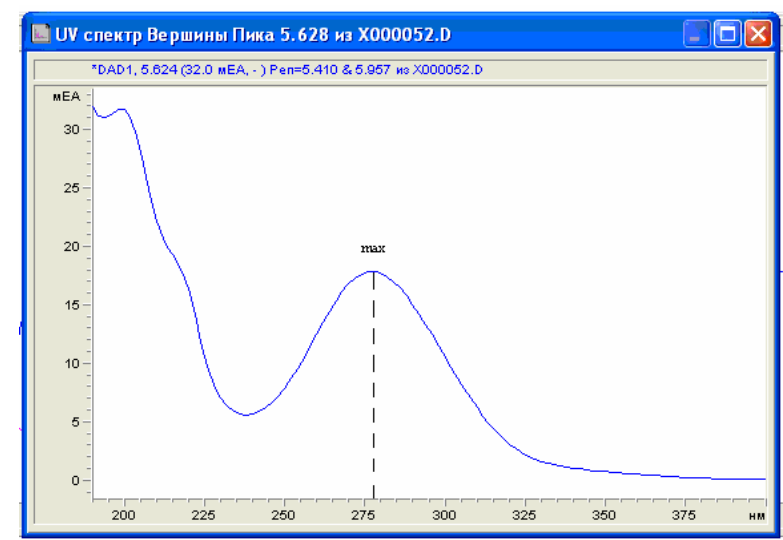

Figure 1. Chloramphenicol absorption spectrum in $50 \%$ water solution of methanol, $\lambda \max =278 \mathrm{~nm}$

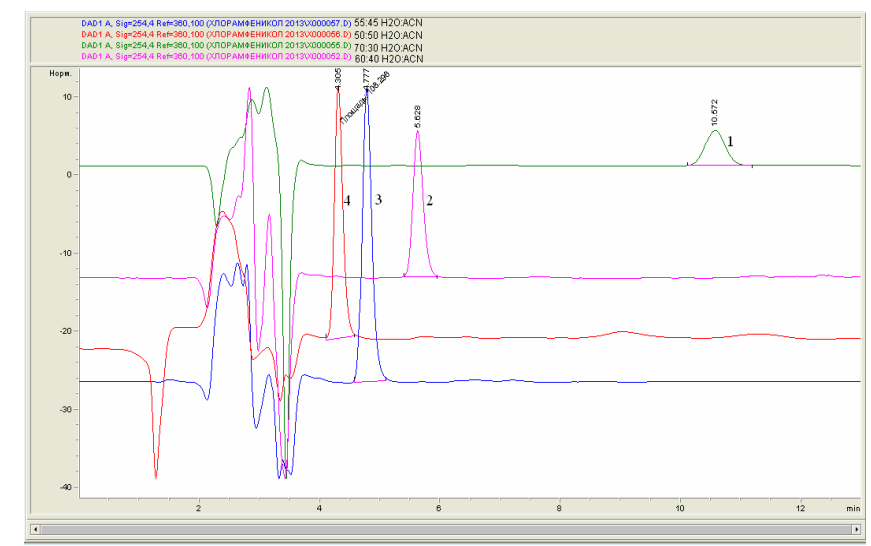

Figure 2. Chromatograms of a chloramphenicol standard solution obtained on Bonus RP column with water : acetonitrile ratios of 70:30 (1), 60:40 (2), 55:45 (3), 50:50 (4)

Based on these results obtained, as the main ion a fragment with $\mathrm{m} / \mathrm{z}=152$ was selected, and as a confirming ion - a fragment with $\mathrm{m} / \mathrm{z}=257$. In the fine-adjustment detector mode formation of daughter ions with $\mathrm{m} / \mathrm{z}=152.1$ and 257.1 was defined more accurately. The value of the optimum voltage for an ion fragmentation device was $126 \mathrm{~V}$, collision cell energy values for daughter ions (CE) were 12 and $4 \mathrm{~V}$. The values obtained are consistent with the data found in the literature [9, 12]. 
Based on the spectral characteristics of chloramphenicol absorption in the ultraviolet spectrum in wavelength range 190-400 nm, a wavelength of $278 \mathrm{~nm}$ was selected as optimal for selective detection of chloramphenicol (Figure 1). Chloramphenicol retention times and signal intensity were determined for each column in different elution modes with varying solvent ratio (water/acetonitrile) in the mobile phase at the elution rate of $0.2 \mathrm{~cm} 3 / \mathrm{min}$ and a column temperature of $25^{\circ} \mathrm{C}$. During investigations it was found that on the Poroshel 120 EC-C18 column with acetonitrile : water ratios of $80: 20,75: 25,70: 30$ and $60: 40$ the analyte was hardly retained, with the retention time less than 1 minute. At the Eclipse XDB-C18 column the optimal elution mode was achieved with acetonitrile : water ratio of 55:45, chloramphenicol retention time 3.08 minutes.

On Bonus RP column the optimal elution of a standard chloramphenicol solution with the account of the retention time, the peak height and symmetry, occurs at a ratio of water and acetonitrile of 60:40 (Figure 2). In further investigations a Bonus RP column was used. Optimal elution conditions on Bonus RP column with a length of $50 \mathrm{~mm}$ and an inner diameter of 4.6 $\mathrm{mm}$, with a particle size of $1.8 \mu \mathrm{m}$ were the following: eluent - a mixture of water and acetonitrile in a $60: 40$ ratio, elution rate $0.2 \mathrm{~cm}^{3} / \mathrm{min}$, column temperature $25^{\circ} \mathrm{C}$. Under these conditions, chloramphenicol retention time is $6.1 \pm 0.3$ minutes. It was found that in the selected elution mode, matrix components are completely separated from chloramphenicol (Figure 3).

Our experimental studies have shown that the rate of chloramphenicol recovery from meat samples with ethyl acetate with petroleum ether purification, is $56.4 \%$.

In the first variant of sample preparation according to QuEChERS method, the chloramphenicol extraction with ethyl acetate was carried out in a neutral medium and the recovery rate was $33.2 \%$. In the second variant, the extraction proceeded in acidic medium (pH $=3$ ), and chloramphenicol recovery rate with ethyl acetate extraction was $41.0 \%$.
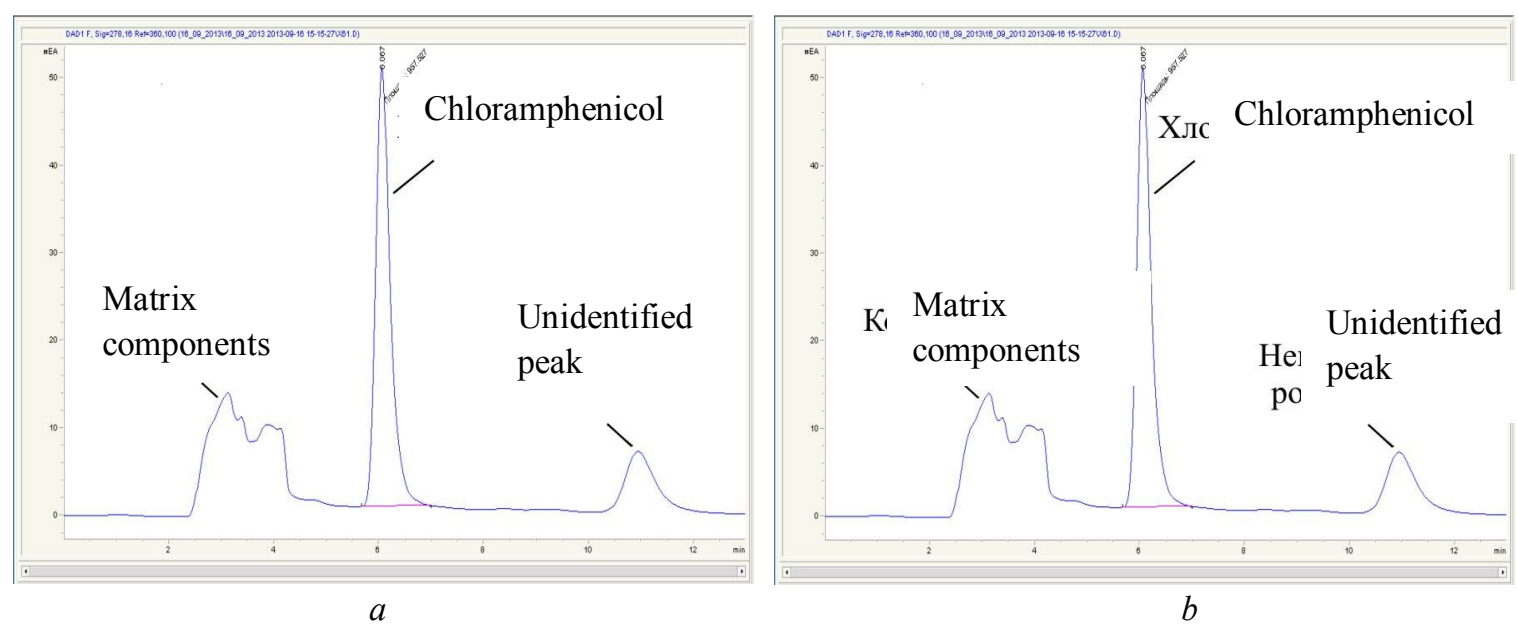

Figure 3. Chromatograms of a meat sample with (s) and without (b) addition of a standard solution of chloramphenicol, obtained using Bonus RP column at the optimal elution mode 
The results of investigations of chloramphenicol recovery rates obtained using various methods of sample preparation, are shown in Table 1.

When comparing different methods of sample preparation, it was found that the maximum rate of antibiotic recovery from ground meat samples is achieved using ethyl acetate as a solvent and extracting agent with subsequent purification of the extract with hexane (see Table 1). The recovery rate is increased from 70 to $99.9 \%$ in correlation with the reduction of chloramphenicol concentration in the sample within the concentration range studied (from 0.00005 to $0.02 \mathrm{mg} / \mathrm{kg}$ ).

The results of investigations on metrological characteristic determination are presented in Table 2.

Table 1

\section{Efficiency of chloramphenicol extraction from meat matrix using different ways of sample preparation}

\begin{tabular}{|c|c|c|c|}
\hline \multirow[b]{2}{*}{ No. } & \multirow[b]{2}{*}{ Sample preparation method } & \multicolumn{2}{|c|}{ Recovery rate, $\%$} \\
\hline & & $\begin{array}{l}\text { With the account of } \\
\text { matrix effect }\end{array}$ & $\begin{array}{l}\text { Without the account of } \\
\text { matrix effect }\end{array}$ \\
\hline 1 & $\begin{array}{l}\text { Liquid extraction with ethyl acetate and } \\
\text { extract purification with hexane }\end{array}$ & $70-99.9$ & 101.3 \\
\hline 2 & $\begin{array}{l}\text { Extraction by QuEChERS method } \\
\text { in neutral medium }\end{array}$ & 33.2 & 91.0 \\
\hline 3 & $\begin{array}{l}\text { Extraction by QuEChERS method } \\
\text { in acidic medium }(\mathrm{pH}=3)\end{array}$ & 41.0 & 77.5 \\
\hline 4 & $\begin{array}{l}\text { Extraction with ethyl acetate and extract } \\
\text { purification with petroleum ether }\end{array}$ & 56.4 & 70.5 \\
\hline
\end{tabular}

Table 2

\section{Values of accuracy, repeatability, reproducibility}

\begin{tabular}{|c|c|c|c|}
\hline $\begin{array}{c}\text { Point in the } \\
\text { chloramphenicol } \\
\text { measuring range, } \\
\mathrm{mg} / \mathrm{kg}\end{array}$ & $\begin{array}{c}\text { Repeatability index } \\
\text { (relative standard deviation } \\
\text { of repeatability), } \\
\sigma \mathrm{r}, \%\end{array}$ & $\begin{array}{c}\text { Reproducibility index } \\
\text { (relative standard deviation } \\
\text { of reproducibility), } \sigma \mathrm{R}, \%\end{array}$ & $\begin{array}{c}\text { Accuracy index } \\
\text { (boundaries of the relative } \\
\text { error with probability } \mathrm{p}= \\
0,95), \pm \delta, \%\end{array}$ \\
\hline 0.000086 & 4.49 & 9.95 & 25.55 \\
\hline 0,0019 & 2.84 & 4.41 & 10.98 \\
\hline 0,018 & 1.22 & 1.81 & 4.64 \\
\hline
\end{tabular}

Based on the results shown in Table 2, it can be concluded that the maximum error of chloramphenicol determination in meat products does not exceed $26 \%$ in the measurement range from 0.00005 to $0.02 \mathrm{mg} / \mathrm{kg}$, inclusive.

During testing of the technique for chloramphenicol determination in meat products $(\mathrm{n}=$ 17), the antibiotic was found in $17.6 \%$ of all the samples analysed in the concentration range from 0.00005 to $0.0019 \mathrm{mg} / \mathrm{kg}$ (maximum content of $0.0019 \mathrm{mg} / \mathrm{kg}$ ). 
Experimental model and measurement studies

\section{Conclusions:}

- A highly sensitive and selective technique of chromatography-mass spectrometric determination of chloramphenicol in meat food products was developed, with a lower limit of detection $0.00005 \mathrm{mg} / \mathrm{kg}$, which allows the control of residual antibiotic content in meat products in accordance with the requirements of the technical regulations of the Customs Union "On safety of meat and meat products "[6];

- The analysis of chloramphenicol residues in samples of meat products (beef, pork, poultry, $\mathrm{n}=17$ ) conducted using this technique, has shown the presence of chloramphenicol in $17.6 \%$ of samples;

- This technique can be recommended for use in laboratories performing quality and safety control of food raw materials and food products.

\section{References}

1. Drugov Ju.S., Rodin A.A. Analiz zagrjaznennyh biosred i pishhevyh produktov: prakticheskoe rukovodstvo [The analysis of contaminated biomedia and food products: practical guidelines]. Moscow: BINOM, Laboratorija znanij, 2010. 294 p.

2. Egorov N.S. Osnovy uchenija ob antibiotikah: uchebnik dlja studentov biologicheskih special'nostej universitetov [The basics of antibiotics studies: for students of biology-related university specialities]. 4-e izd. Moscow: Vysshaja shkola, 1986. 448 p.

3. Onishhenko G.G., Zajceva N.V., Ulanova T.S. Kontrol' soderzhanija himicheskih soedinenij i jelementov $\mathrm{v}$

biologicheskih sredah: rukovodstvo [Monitoring of the levels of chemical compounds and elements in biological media: guidelines]. Perm': Knizhnyj format, 2011. 520 p.

4. Metodicheskie ukazanija «Opredelenie ostatochnyh kolichestv levomicetina (hloramfenikola, hlormicetina) $\mathrm{v}$ produktah zhivotnogo proishozhdenija metodom vysokojeffektivnoj zhidkostnoj hromatografii i immunofermentnogo analiza» MUK 4.1.191204 [Methodical guidelines "The determination of the residual quantities of laevomycetin (chloramphenicol, chloromycetin) in food products of animal origin using high-performance liquid chromatography and ELISA» MUK 4.1.1912-04]. Moscow: Federal'nyj centr Gossanjepidnadzora Minzdrava Rossii, 2004. 26 p.

5. Panin A.N., Komarov A.A. Problemy analiticheskogo kontrolja bezopasnosti kormov i produkcii zhivotnovodstva [Issues of analytical monitoring of feed and livestock product safety]. Zhurnal Rossijskogo himicheskogo obshhestva im. D.I. Mendeleeva, 2005, vol. XLIX, no. 3 , pp. $71-82$.

6. Tehnicheskij reglament Tamozhennogo sojuza «O bezopasnosti mjasa i mjasnoj produkcii» TR TS

034/2013: utverzhden resheniem Soveta Evrazijskoj jekonomicheskoj komissii 9 oktjabrja 2013 g. No. 68 [Customs Union Technical Regulation no. 68 «On meat and meat products safety» TR TS 034/2013: approved by the Council of the Eurasian Economic Commission on 9 October 2013]. Available at: http://socialvet.ru/ blog/vetrinarni_meri_tsouz/3270.html.

7. Codex Alimentarius Commission Maximum Residue Limits for Veterinary Drugs in Foods Updated as at the 35th Session of the Codex Alimentarius Commission (July 2012) $\mathrm{CAC} / \mathrm{MRL}$ 
http://www.codexalimentarius.org/input/download/standards/45/MRL2_e.pdf.

8. European Committee for Veterinary Medicinal Products. Chloramphenicol summary report. European Agency for the Evaluation of Medicinal Products, 1994. Available at: http://www.emea.eu.int/pdfs/vet/mrls/chloramphenicol.pdf.

9. Heidi R., James S., Hurlbut J. LC/MS/MS Analysis of Chloramphenicol in Crab Meat. Laboratory Information Bulletin. U.S. Food and Drug Administration, Pacific Regional Lab Northwest, 22201 23rd Drive SE, Bothell, WA 98021. 2003, April, vol. 19, no. 4. Available at: http://www.fda.gov/Food/FoodScienceResearch/LaboratoryMethods/ucm1 13380.htm.

10. IARC Monographs on the evaluation of carcinogenic risk of chemicals to humans. Chloramphenicol, Lyon: IARCPress, 1990, vol. 50, pp. 169-193.

11. Jimenez J.J., Jimenez J.G., Daghistani D. and Yunis A.A. Interaction of chloramphenicol and metabolites with colony stimulating factors: possible role in chloramphenicol-induced bone marrow injury. Am J Med Sci, 1990, vol. 300, pp. 350-353.

12. Neuhaus V., Hurlbut J., Hammack W. LC/MS/MS Analysis of Chloramphenicol in Shrimp. Laboratory

Information Bulletin, 2002, no. 4290. $166-169$.

13. Plumb D.C. Veterinary Drug Handbook. Ames: Iowa State Press, 2002, 4th Ed., pp.

14. Wang J., Macneil J.D., Kay J.F. Chemical analysis of antibiotic residues in food. Wiley, 2012. $353 \mathrm{p}$. 